\title{
Is secondary hyperparathyroidism-related myelofibrosis a negative prognostic factor for kidney transplant outcome?
}

\author{
Maurizio Bellavia, Maria Concetta Gioviale, Giuseppe Damiano, Vincenzo Davide Palumbo, \\ Francesco Cacciabaudo, Roberta Altomare, Giuseppe Buscemi, Attilio Ignazio Lo Monte* \\ Department of Surgical and Oncological Sciences, University of Palermo, School of Medicine, Palermo, Italy
}

\section{A R T I C L E I N F O}

Article history:

Received 7 March 2011

Accepted 12 June 2011

\begin{abstract}
A B S T R A C T
Secondary hyperparathyroidism (HP) presenting with hypocalcemia and subsequent increased parathormone (PTH), is mainly identified in patients with chronic renal failure, which has been associated with variable degrees of bone marrow fibrosis.

For suitable patients with end-stage renal disease (ESRD), kidney transplantation is recognized as the therapy of choice, being superior to dialysis in terms of quality of life and long-term mortality risk; in this regard interesting data show that increased time on dialysis prior to kidney transplantation is associated with decreased graft and patient survival.

In our opinion an important and until now underestimated determinant of graft survival is the proper activity of bone marrow because of the emerging role of hematopoietic stem cells (HSC) in repair of ischemia/reperfusion (IR) damage. We postulate that in ESRD patients, who usually undergo long dialytic treatment, a myelofibrosis caused by an overt secondary HP could drastically decrease the HSC potential for IR damage repair after kidney transplant; this could irremediably lead to a delay in graft function with all related complicances.

If the curative role of bone marrow-derived stem cells was confirmed by more data obtained in experimental animal models, it could be possible to try a cellular-based therapeutic approach in the management of ESRD patients which are in waiting list for a kidney transplant.
\end{abstract}

(c) 2011 Elsevier Ltd. All rights reserved.

\section{Introduction}

Bone marrow fibrosis occurs in pathological states that characterize idiopathic myelofibrosis $[1,2]$ and hyperparathyroid bone disease [3]. While recent investigations have identified important constituents within fibrotic marrow in patients who have certain hematologic malignancies, little is known about the pathogenesis of marrow fibrosis that occurs in patients with renal osteodystrophy.

Specifically, questions regarding fibrosis composition, its genesis and the potential role of parathyroid hormone (PTH) in the fibrous replacement of the marrow space remain to be answered.

As seen from studies of idiopathic myelofibrosis, growth factors and cytokines are believed to promote a marrow proliferative response and the accumulation of extracellular matrix proteins [2]. Whether these factors are also implicated in uremic bone dis-

\footnotetext{
* Corresponding author. Address: Department of Surgical and Oncological Sciences, University of Palermo, School of Medicine, Via del Vespro, 129, 90127 Palermo, Italy. Tel.: +39 09165526 27; mobile: +39 3297506 851; fax: +39 091 6552836 .

E-mail address: ailomonte@unipa.it (A.I. Lo Monte).
}

ease is unknown. However, cytokines and locally derived growth factors have important roles in regulating normal bone metabolism and circulating levels of specific cytokines are elevated in renal failure $[4,5]$.

Cytokines are particularly important in modulating the bone resorptive phase of the remodeling cycle [6], thus the finding that PTH can stimulate selective cytokine synthesis [7] suggests that hyperparathyroidism may be a significant stimulus for cytokine accumulation in renal osteodystrophy.

There has been much interest in the reparative and angiogenic properties of stem cells from bone marrow [8-10] and several studies in mouse models of kidney disease have shown that mouse mesenchymal stromal cells of bone marrow can prevent or attenuate kidney injury, possibly by paracrine or systemic secretory mechanisms. However, the possible angiogenic role of hematopoietic stem/progenitor cells (HSPCs) in kidney repair has been little explored, and no studies have ascertained the practicability of harvesting human HSPCs in cell therapy to promote organ repair and regeneration [11].

The kidney peritubular microvasculature has received increasing attention recently because this fragile vasculature may not regenerate normally after injury. This may predispose to chronic 
ischemia of the kidney $[12,13]$ triggering chronic inflammation, tubular atrophy, and interstitial fibrosis, hallmarks of chronic kidney disease.

\section{Hypothesis}

Ischemia and reperfusion (I/R) injury is the first insult to a transplanted organ. In renal grafts $\mathrm{I} / \mathrm{R}$ injury is followed by delayed graft function (DGF), which is the most common complication in the immediate period, when the transplant is performed from a deceased donor. The immediate consequences of $I / R$ injury are prolonged hospitalization, increased costs, and greater complexity of immunosuppressive drug management. Some trials have demonstrated association between DGF and risk of acute rejection episodes (ARE); therefore, I/R injury may be related to a reduced graft survival $[14,15]$.

We believe that one of the main causes of DRG could be a myelofibrosis secondary to an overt secondary hyperparathyroidism arisen in long-term dyalisis patients who are in waiting list for a kidney transplant. Bone marrow fibrosis could infact lead to a decreased level of HSC and finally to a drastic compromission of the repair of IR damage [16].

\section{Evaluation of hypothesis and discussion}

Recent studies have shown that CD34+ hematopoietic cells, originating from the bone marrow, can differentiate into an endothelial phenotype and form a subpopulation of circulating cells called endothelial progenitor cells (EPCs) [17].

It has been shown that in uremic patients high serum level of parathyroid hormone (PTH) was associated with a decrease in circulating CD34+ cells [18]; authors suggest a role of uremic toxins in such an inverse relation. We think that another explanation could involve bone marrow fibrosis which is sometimes found in association with hyperparathyroidism; from this point of view the low level of circulating CD34+ cells could not only be caused by toxic activity of uric acid and related compounds $[19,20]$ but also it could correlate with a decreased production of these cells in a fibrotic bone marrow.

In favor of this argument published data by Jourde-Chiche et al. [21] showed that in hemodyalisis (HD) patients CD34+ CD133+ immature progenitor cells number was negatively correlated with the levels of uremic toxins $\beta 2$-microglobulin and indole-3acetic acid, but myeloid endothelial progenitor cells number positively correlated with markers of vascular injury assessed by measuring aortic pulse wave velocity and plasma level of endothelial microparticles.

This evidence could be explained postulating that uremic toxins exerted a deleterious effect on progenitor cells early in the differentiation process, but also that vascular injury stimulated a mobilization of EPC from bone marrow. Interestingly all HD patients have not a very significant alteration of calcium/phosphorus metabolism; consequently none of them suffer from an overt secondary hyperparathyroidism which could have caused a myelofibrosis.

It has been also reported that in patients on long-term hemodialysis the total number of EPC increased but the cells were characterized by pronounced functional impairment particularly in term of reduced migratory activity and ability to adhere to matrix proteins [22]; in this case it should be emphasized that all patients have a high serum level of PTH (about $250 \mathrm{pg} / \mathrm{mL}$ ) which is an hallmark of HP. It could be possible to postulate that also in this case a not properly diagnosed myelofibrosis, secondary to HP, could have compromised the ability of bone marrow to produce functional EPC.

\section{Consequences of hypothesis}

Bone marrow-derived stem cells appear to have a capacity for trans differentiation and to repair damaged renal tissue by replacing tubular epithelial cells [23], mesangial cells [24,25], endothelial cells [26] and even podocytes [27,28]. Although bone marrow contains several cell types including hematopoietic stem cells (HSC), mesenchymal stromal cells (MSC) and endothelial progenitor cells (EPC), engraftment of bone marrow-derived cells to kidney is most likely to have been due to the MSC population [29,30].

Patients suffering from renal failure and related secondary hyperparathyroidism, subjected to a dialysis treatment and in waiting list for a kidney transplant, could have a decreased number of different types of bone marrow derived progenitor cells (BMDC) because of the onset of a myelofibrosis [31]. In this cases, if the regenerative role of BMDC was confirmed in experimental animal models, it could be possible to plan a blood collection of these cells before the onset of myelofibrosis with the aim to infuse them in situ again after kidney transplant helping the functional recovery of graft [32].

\section{Conflict of interest statement}

All authors declare the absence of any employment, consultancies, stock ownership, honoraria, paid expert testimony, patent applications/registrations, and grants which could inappropriately influence their work.

\section{References}

[1] Hasselbach H. Idiopathic myelofibrosis: A review. Eur J Haematol 1990;45:65-92.

[2] Reilly JT. Pathogenesis of idiopathic myelofibrosis: Role of growth factors. J Clin Pathol 1992;45:461-4.

[3] Hruska KA, Teitelbaum SL. Renal osteodystrophy. $N$ Engl J Med 1995;333:166-74.

[4] Herbelin A, Urena P, Nguyen AT, Zingraff J, Descamps-Latscha B. Elevated circulating levels of interleukin-6 in patients with chronic renal failure. Kidney Int 1991;39:954-60.

[5] Herbelin A, Nguyen AT, Zingraff J, Urena P, Descamps-Latscha B. Influence of uremia and hemodialysis on circulating interleukin-1 and tumor necrosis factor $\alpha$. Kidney Int 1990;37:116-25.

[6] Yoneda T. Cytokines in bone: local translators in cell-to-cell communications. In: Noda M, editor. Cellular and Molecular Biology of Bone. San Diego, CA, USA: Academic Press; 1993.

[7] Greenfield EM, Shaw SM, Gornic SA, Banks MA. Adenyl cyclase and interleukin 6 are downstream effectors of parathyroid hormone resulting in stimulation of bone resorption. J Clin Invest 1995;96:1238-44.

[8] Li B, Morioka T, Uchiyama M, Oite T. Bone marrow cell infusion ameliorates progressive glomerulosclerosis in an experimental rat model. Kidney Int 2006;69:323-30.

[9] Togel F, Cohen A, Zhang P, Yang Y, Hu Z, Westenfelder C. Autologous and allogeneic marrow stromal cells are safe and effective for the treatment of acute kidney injury. Stem Cells Dev 2009;18:475-85.

[10] Van Huyen JP, Smadja DM, Bruneval P, et al. Bone marrow-derived mononuclear cell therapy induces distal angiogenesis after local injection in critical leg ischemia. Mod Pathol 2008;21:837-46.

[11] Dekel B, Shezen E, Even-Tov-Friedman S, et al. Transplantation of human hematopoietic stem cells into ischemic and growing kidneys suggests a role in vasculogenesis but not tubulogenesis. Stem Cells 2006;24:1185-93.

[12] Basile DP. The endothelial cell in ischemic acute kidney injury: implications for acute and chronic function. Kidney Int 2007;72:151-6.

[13] Basile DP. Challenges of targeting vascular stability in acute kidney injury Kidney Int 2008;74:257-8

[14] Shoskes DA. Cecka JM: Deleterious effects of delayed graft function in cadaveric renal transplant recipients independent of acute rejection. Transplantation 1998;66:1697-701.

[15] Ojo AO, Wolfe RA, Held PJ, Port FK, Schmouder RL. Delayed graft function: risk factors and implications for renal allograft survival. Transplantation 1998;65:757-8.

[16] Kwon O, Miller S, Li N, Khan A, Kadry Z, Uemura T. Bone Marrow-derived Endothelial Progenitor Cells and Endothelial Cells May Contribute to Endothelial Repair in the Kidney Immediately After Ischemia-Reperfusion. J Histochem Cytochem 2010;58:687-94. 
[17] Hristov M, Weber C. Endothelial progenitor cells: characterization, pathophysiology, and possible clinical relevance. J Cell Mol Med 2004;8:498-508.

[18] Lomonte C, Derosa C, Vernaglione L, et al. Serum parathyroid hormone and phosphate influence the levels of circulating CD34+ cells in uremia. J Nephrol 2010;23:693-8.

[19] Buerni M, Costa C, Floccari F, et al. Genomic damage in endothelial progenitor cells from uremic patients in hemodialysis. J Nephrol 2010;23:328-34

[20] Pernice F, Floccari F, Nostro L, et al. Oxidative stress, sister chromatid exchanges and apoptosis in the pathogenesis of lymphocytopenia in ESRD patients. J Nephrol 2006;19:613-20.

[21] Jourde-Chiche N, Dou L, Sabatier F, Calaf R, Cerini C, Robert S. Levels of circulating endothelial progenitor cells are related to uremic toxins and vascular injury in hemodialysis patients. J Thromb Haemostasis 2009;7:1576-84

[22] Herbrig K, Pistrosch F, Oelschlaegel U, et al. Increased total number but impaired migratory activity and adhesion of endothelial progenitor cells in patients on long-term hemodialysis. Am J Kidney Dis 2004;44:840-9.

[23] Poulsom R, Forbes SJ, Hodivala-Dilke K, et al. Bone marrow contributes to renal parenchymal turnover and regeneration. J Pathol 2001;195:229-35.

[24] Imasawa T, Utsunomiya Y, Kawamura T, et al. The potential of bone marrowderived cells to differentiate to glomerular mesangial cells. J Am Soc Nephrol 2001;12:1401-9.
[25] Ito T, Suzuki A, Imai E, Okabe M, Hori M. Bone marrow is a reservoir of repopulating mesangial cells during glomerular remodelling. J Am Soc Nephrol 2001;12:2625-35

[26] Rookmaaker MB, Smits AM, Tolboom H, et al. Bone-marrow derived cells contribute to glomerular endothelial repair in experimental glomerulonephritis. Am J Pathol 2003;163:553-62.

[27] Sugimoto H, Mundel TM, Sund M, Xie L, Cosgrove D, Kalluri R. Bone-marrowderived stem cells repair basement membrane collagen defects and reverse genetic kidney disease. Proc Natl Acad Sci USA 2006;103:7321-6.

[28] Prodromidi EI, Poulsom R, Jeffery R, et al. Bone marrow-derived cells contribute to podocyte regeneration and amelioration of renal disease in a mouse model of Alport syndrome. Stem Cells 2006;24:2448-55.

[29] Morigi M, Imberti B, Zoja C, et al. Mesenchymal stem cells are renotropic, helping to repair the kidney and improve function in acute renal failure. J Am Soc Nephrol 2004;15:1794-804.

[30] Krause D, Cantley LG. Bone marrow plasticity revisited: protection or differentiation in the kidney tubule? J Clin Invest 2005;115:1705-8.

[31] Lim DJ, Oh EJ, Park CW, et al. Pancytopenia and secondary myelofibrosis could be induced by primary hyperparathyroidism. Int Jnl Lab Hem 2007;29:464-8.

[32] Akihama S, Sato K, Satoh S, et al. Bone marrow-derived cells mobilized by granulocyte-colony stimulating factor facilitate vascular regeneration in mouse kidney after ischemia/reperfusion injury. Tohoku J Exp Med 2007;213:341-9. 